\title{
THE MECHANISM OF POLYURIA OF DIABETES INSIPIDUS IN MAN. THE EFFECT OF OSMOTIC LOADING
}

\author{
By WILLIAM A. BRODSKY 1 AND S. RAPOPORT \\ (From the Children's Hospital Research Foundation and the Department of Pediatrics, Uni- \\ versity of Cincinnati College of Medicine, Cincinnati)
}

(Submitted for publication July 1, 1950; accepted, December 21, 1950)

\section{INTRODUCTION}

Although there is general agreement on the role of the hypothalamic-hypophyseal region in the genesis of diabetes insipidus (1), the nature of the renal defect which results in the excretion of a copious and dilute urine has remained obscure. The excretion of a hypotonic urine in diabetes insipidus may be explained by any of three hypotheses: (a) the delivery of a hypotonic fluid from the proximal tubule, or (b) an isotonic proximal urine with solute reabsorption in the distal tubule, and (c) an isotonic proximal urine with water secretion in the distal tubule.

A complete decision with regard to these hypotheses is not at hand. Hypothesis (a), assuming a hypotonic proximal fluid (2), although presumably based on the observations of Walker and his associates (3) would require a much greater hypotonicity than ever observed in order to explain the low urinary osmolarity of diabetes insipidus. Hypothesis (b) (4), most widely accepted at present, holds that the polyuria is due to lack of water reabsorption in the distal renal tubule. Normally $7 / 8$ of the glomerular filtrate is reabsorbed isotonically in the proximal tubule, while $1 / 8$, under the hormonal control of the hypothalamic-hypophyseal region, may be reabsorbed in the distal tubule. Lack of hormone results in a maximum diuresis of about $1 / 8$ of the glomerular filtration rate. This hypothesis, in order to explain the dilute urine of diabetes insipidus, requires the assumption of solute reabsorption in the distal tubule, with a distal reabsorbate of unspecified but hypertonic osmolarity. Hypothesis (c), popular before the general acceptance of the glomerular filtration theory, has for its major objection the demonstrated proportionality between urine flow and arterial pressure in the isolated kidney (5).

\footnotetext{
1 Present address: University of Louisville, School of Medicine, Department of Pediatrics, Louisville, Ky.
}

It appeared that osmotic diuresis in patients with diabetes insipidus might offer a means of testing the three hypotheses. Given an unchanged glomerular filtration rate, and assuming with Shannon (2) that the urine formed in diabetes insipidus resembles that which is delivered to the distal tubule, no significant change in urinary osmolarity should occur after loading. The predictions of hypothesis $(b)$ depend on the nature of the distal reabsorptive process assumed. Hypothesis (c) would require that, given a constant rate of secretion of hypotonic urine prior to loading, the increment of urine flow during osmotic diuresis, representing additional proximal fluid, be nearly isotonic with plasma.

Osmotic diuresis with mannitol loading was produced in three subjects with diabetes insipidus. The rates of urine flow and solute excretion before and during loading as well as those of glomerular filtration and renal plasma flow were studied.

\section{EXPERIMENTAL}

The subjects of the present study were one woman, 19 years, and two boys, six and 12 years of age, with diabetes insipidus. They had abstained from food and drink for four to eight hours, and from pitressin medication for two to three days preceding the test.

Mannitol, in $25 \%$ solution, was administered as the loading solute. Two priming injections, the first of 180 and the second of 90 milliosmoles (mOsm.) per $1.73 \mathrm{M}^{2}$, calculated to add 20 and $10 \mathrm{mOsm}$, respectively, per liter of distribution volume, were given, followed by a maintenance infusion in the amount of $1 \%$ of the priming dose per minute. All infusion fluids had sufficient paraaminohippurate (PAH) added to maintain a plasma level of about $3 \mathrm{mgm} . / 100 \mathrm{cc}$., for the measurement of renal plasma flow. After a 20 minute period of equilibration following the priming infusion, urine was collected for two or three periods of 15-20 minutes each at both loading levels and blood samples were drawn at appropriate intervals. The urine and blood were analysed for mannitol, urea, sodium, potassium, chloride, and РАH. Osmotic activity was determined directly by the freezing 
point in urine, and calculated from the determineds solutes in blood. The analytical techniques used have been described (6).

Toward the end of the test periods, the patients became weak and listless and the skin felt cold to touch. One patient, D. S., complained of headache, and another vomited repeatedly when he drank water after the test.

The tests were repeated on two of the patients, D. E. and I. W., after an interval of three to four weeks, while they were receiving pitressin. Five-tenths cc. of an aqueous solution of pitressin (10 pressor units) was given intramuscularly every three hours for 20 hours preceding, and every two hours during the test. On pitressin, the patients were able to withstand 16 hours of water deprivation, and experienced no untoward symptoms during the loading procedure.

${ }^{2}$ Osmotic Activity of Plasma $=[2(\mathrm{Na}+\mathrm{K})-8+$ Urea + Mannitol] $\times \gamma$, where $\gamma$, the activity coefficient of plasma, was assumed to be 0.92 .

\section{RESULTS}

Table I presents results on three patients obtained in five tests comprising 40 periods of urine collection. Data include the corrected minute volume of urine, the osmolarity of urine and plasma, clearance of mannitol and PAH, and the filtration fraction.

It may be seen that during the pre-loading periods, the urine flow remained at high values of 5.1$11 \mathrm{cc} / \mathrm{min}$., despite the hydropenic state of the subjects. The urine was hypotonic, its osmolarity reaching values as low as $56 \mathrm{mOsm}$./L., or approximately $1 / 6$ that of plasma. After loading, with increasing flows, the osmolarity of the urine increased. The highest value obtained, 232 mOsm./L., was slightly more than $2 / 3$ of the plasma

TABLE I

Urine flow, osmolarity, and clearances of mannitol and $P A H$ during mannitol diuresis

I. W., 2-25-50, S.A. $1.45 \mathrm{M}^{2}$, Mannitol, No pitressin:

\begin{tabular}{|c|c|c|c|c|c|c|c|}
\hline Period no. & Concurrent time & Urine volume & $\begin{array}{c}\text { Osmolarity } \\
\text { urine }\end{array}$ & $\begin{array}{l}\text { Osmolarity } \\
\text { plasma }\end{array}$ & $\begin{array}{l}\text { Clearance } \\
\text { mannitol }\end{array}$ & Clearance PAH & $\frac{\text { Clearance mann. }}{\text { Clearance PAH }}$ \\
\hline \multirow[t]{2}{*}{$\begin{array}{l}P-1 \\
P-2 \\
P-3\end{array}$} & $\begin{array}{l}\text { mix. } \\
-76 \text { to }-46 \\
-46 \text { to }-18 \\
-18 \text { to }-6\end{array}$ & $\begin{array}{c}\text { cc. } / \min . / 1.73 \mathrm{M}^{2} \\
5.14 \\
6.76 \\
7.31\end{array}$ & $\begin{array}{c}\text { mosm./L } \\
67 \\
58 \\
56\end{array}$ & $\begin{array}{c}m \text { Osm./L. } \\
285\end{array}$ & cc./min./1.73 $\mathrm{M}^{2}$ & cc./min. $/ 1.73 \mathrm{M}^{2}$ & \\
\hline & 0 to 7.0 & & \multicolumn{4}{|c|}{121 cc. of $25 \%$ Mannitol } & \\
\hline \multirow[t]{2}{*}{$\begin{array}{c}X-I \\
1 \\
2\end{array}$} & $\begin{array}{l}-6 \text { to } 20 \\
20 \text { to } 30 \\
30 \text { to } 40\end{array}$ & $\begin{array}{l}14.0 \\
15.5 \\
14.4\end{array}$ & $\begin{array}{l}124 \\
158 \\
155\end{array}$ & $\begin{array}{l}291 \\
295\end{array}$ & $\begin{array}{r}104.2 \\
92.2\end{array}$ & $\begin{array}{l}498 \\
451\end{array}$ & $\begin{array}{l}0.21 \\
0.20\end{array}$ \\
\hline & 42 to 50 & & \multicolumn{3}{|c|}{104 cc.of $25 \%$ Mannitol } & & \\
\hline $\begin{array}{c}\mathrm{X}-\mathrm{II} \\
3 \\
4 \\
5\end{array}$ & $\begin{array}{l}40 \text { to } 62 \\
62 \text { to } 80 \\
80 \text { to } 90 \\
90 \text { to } 102\end{array}$ & $\begin{array}{l}19.6 \\
17.6 \\
14.9 \\
14.5\end{array}$ & $\begin{array}{l}185 \\
208 \\
228 \\
232\end{array}$ & $\begin{array}{l}300 \\
304\end{array}$ & $\begin{array}{l}90.8 \\
84.9\end{array}$ & $\begin{array}{l}496 \\
472\end{array}$ & $\begin{array}{l}0.18 \\
0.18\end{array}$ \\
\hline
\end{tabular}

D. E., 12-8-49, S. A. $0.81 \mathrm{M}^{2}$, Mannitol, No pitressin:

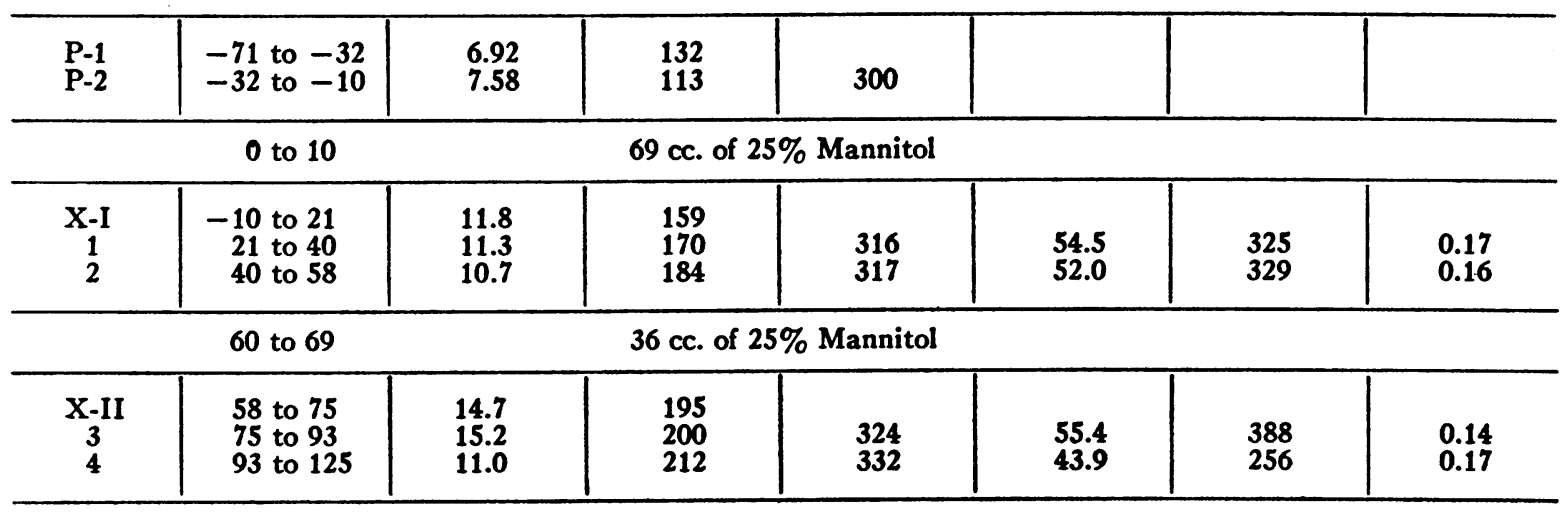


TABLE I-Continued

D. S., 2-6-50, S. A. $0.83 \mathrm{M}^{2}$, Mannitol, No pitressin:

\begin{tabular}{|c|c|c|c|c|c|c|c|}
\hline Period no. & Concurrent time & Urine volume & $\begin{array}{c}\text { Osmolarity } \\
\text { urine }\end{array}$ & $\begin{array}{c}\text { Osmolarity } \\
\text { plasma }\end{array}$ & $\begin{array}{l}\text { Clearance } \\
\text { mannitol }\end{array}$ & Clearance PAH & $\begin{array}{l}\text { Clearance mann. } \\
\text { Clearance PAH }\end{array}$ \\
\hline$P-1$ & $\begin{array}{c}\min . \\
-69 \text { to }-37\end{array}$ & $\begin{array}{c}c c . / \min . / 1.73 \mathrm{M}^{2} \\
10.7\end{array}$ & $\begin{array}{c}m 0 s m . / L \\
56\end{array}$ & $m O s m . / L$ & $c c . / \min . / 1.73 \mathrm{M}^{2}$ & $c c . / \min . / 1.73 \mathrm{M}^{2}$ & \\
\hline \multicolumn{8}{|c|}{0 to $10 \quad 71 \mathrm{cc}$. of $25 \%$ Mannitol I.V. } \\
\hline $\begin{array}{c}\mathrm{X}-\mathrm{I} \\
1 \\
2\end{array}$ & $\begin{array}{r}-37 \text { to } 16 \\
16 \text { to } 26 \\
26 \text { to } 37\end{array}$ & $\begin{array}{l}13.1 \\
27.9 \\
18.8\end{array}$ & $\begin{array}{r}79 \\
130 \\
135\end{array}$ & & & & \\
\hline \multicolumn{8}{|c|}{39 to $49 \quad 37$ cc. of $25 \%$ Mannitol } \\
\hline$\underset{3}{\mathrm{X}-\mathrm{II}}$ & $\begin{array}{l}37 \text { to } 50 \\
50 \text { to } 59\end{array}$ & $\begin{array}{l}19.8 \\
21.0\end{array}$ & $\begin{array}{l}147 \\
146\end{array}$ & & & & \\
\hline \multicolumn{8}{|c|}{ D. E., 1-11-50, S.A. $0.82 M^{2}$, Mannitol, Pitressin: } \\
\hline $\begin{array}{l}\text { P-1 } \\
\text { P-2 }\end{array}$ & $\begin{array}{l}-94 \text { to }-46 \\
-46 \text { to }-12\end{array}$ & $\begin{array}{l}1.15 \\
1.52\end{array}$ & $\begin{array}{l}777 \\
747\end{array}$ & 263 & & & \\
\hline \multicolumn{8}{|c|}{0 to $7.4 \quad 61 \mathrm{cc}$. of $25 \%$ Mannitol } \\
\hline $\begin{array}{c}\mathrm{X}-\mathrm{I} \\
1 \\
2\end{array}$ & $\begin{array}{r}-12 \text { to } 35 \\
35 \text { to } 60 \\
60 \text { to } 78\end{array}$ & $\begin{array}{l}5.91 \\
6.50 \\
6.18\end{array}$ & $\begin{array}{l}583 \\
605 \\
602\end{array}$ & $\begin{array}{l}269 \\
271\end{array}$ & $\begin{array}{l}145.5 \\
135.2\end{array}$ & $\begin{array}{l}597 \\
554\end{array}$ & $\begin{array}{l}0.24 \\
0.24\end{array}$ \\
\hline \multicolumn{8}{|c|}{79 to $84 \quad 40$ cc. of $25 \%$ Mannitol } \\
\hline $\begin{array}{c}X-I I \\
3 \\
4\end{array}$ & $\begin{array}{r}78 \text { to } 102 \\
102 \text { to } 130 \\
130 \text { to } 157\end{array}$ & $\begin{array}{l}8.29 \\
8.31 \\
8.84\end{array}$ & $\begin{array}{l}551 \\
538 \\
511\end{array}$ & $\begin{array}{l}277 \\
277\end{array}$ & $\begin{array}{l}118.5 \\
132.8\end{array}$ & $\begin{array}{l}513 \\
469\end{array}$ & $\begin{array}{l}0.23 \\
0.28\end{array}$ \\
\hline \multicolumn{8}{|c|}{ I. W., 3-25-50, S.A. $1.45 M^{2}$, Mannitol, Pitressin: } \\
\hline $\begin{array}{l}\text { P-1 } \\
\text { P-2 }\end{array}$ & $\begin{array}{l}-73 \text { to }-40 \\
-40 \text { to }-3\end{array}$ & $\begin{array}{l}0.43 \\
0.76\end{array}$ & $\begin{array}{l}605 \\
677\end{array}$ & 303 & & & \\
\hline \multicolumn{8}{|c|}{0 to $11 \quad 121$ cc. of $25 \%$ Mannitol } \\
\hline $\begin{array}{c}\mathrm{X}-\mathrm{I} \\
1 \\
2\end{array}$ & $\begin{array}{r}-3 \text { to } 25 \\
25 \text { to } 35 \\
35 \text { to } 54\end{array}$ & $\begin{array}{l}3.50 \\
3.62 \\
4.15\end{array}$ & $\begin{array}{l}606 \\
606 \\
611\end{array}$ & $\begin{array}{l}307 \\
307\end{array}$ & $\begin{array}{l}95.6 \\
107\end{array}$ & $\begin{array}{l}565 \\
606\end{array}$ & $\begin{array}{l}0.17 \\
0.18\end{array}$ \\
\hline \multicolumn{3}{|c|}{58 to 69} & 104 cc. of & o Mannitol & & & \\
\hline $\begin{array}{c}\text { X-II } \\
3 \\
4\end{array}$ & $\begin{array}{l}54 \text { to } 79 \\
79 \text { to } 89 \\
89 \text { to } 99\end{array}$ & $\begin{array}{l}4.83 \\
5.33 \\
6.45\end{array}$ & $\begin{array}{l}624 \\
608 \\
605\end{array}$ & $\begin{array}{l}314 \\
318\end{array}$ & $\begin{array}{l}95.5 \\
104\end{array}$ & $\begin{array}{l}405 \\
510\end{array}$ & $\begin{array}{l}0.24 \\
0.20\end{array}$ \\
\hline
\end{tabular}

osmolarity. Urine flows increased two- to threefold over the preliminary rates to values of $15-28$ $\mathrm{cc} . / \mathrm{min}$. These effects are the reverse of those observed in normal hydropenic subjects during solute loading, where with increasing flows urinary osmolarity decreased but remained greater than that of plasma (6).

The last two tests shown in the table were per- formed on patients D. E. and I. W. while they were under the influence of pitressin. During the pre-loading periods, the urine flow varied between 0.43 to $1.15 \mathrm{cc} . / \mathrm{min}^{3}$ After loading, with flows attaining values as high as $8.8 \mathrm{cc} . / \mathrm{min}$., urinary

3 The high preliminary flows observed in patient D. E. perhaps may be explained by a mild electrolyturetic action of the pitressin. 
osmolarity decreased to a value of $511 \mathrm{mOsm} . / \mathrm{L}$. The results were essentially the same as those observed in normal hydropenic subjects after mannitol loading (6).

The clearances of mannitol and PAH were low in patient D. E., a 12 year old dwarfed boy. When the test was repeated with the patient on pitressin, the clearance of mannitol increased three-fold and that of PAH, two-fold, with an increase in the filtration fraction. Decreases in filtration rate have been observed in dogs with diabetes insipidus (7). In the case of patient I. W., the clearances of both mannitol and PAH were normal and did not change significantly after pitressin administration.

It is evident that in each patient, the clearance values remained unchanged during the tests. Although no clearances were determined in the preliminary periods, one may assume that they changed little with loading both from the constancy of the clearances at different levels of loading and from data in the literature on normal subjects and dogs (8).

The independence of urine flow from changes of filtration rate or renal plasma flow is evident from the data shown in the table.

Figure 1 contains a plot of the values for urine flow versus solute load. The curve drawn is based on the data of nine normal hydropenic subjects during mannitol diuresis. It can be seen that for a given solute load, the patients with diabetes insipidus excreted urine at a rate two to three times greater than normal subjects. On the other hand, when treated with pitressin, their response was normal. A dependence of urinary volume on the "total milliosmolar excretion rate" in patients with diabetes insipidus has been noted (9). It is of interest that both patients on pitressin excreted solutes in an identical manner despite sizeable differences in their filtration rate.

Figure 2 shows plots of losses of sodium, chlo-

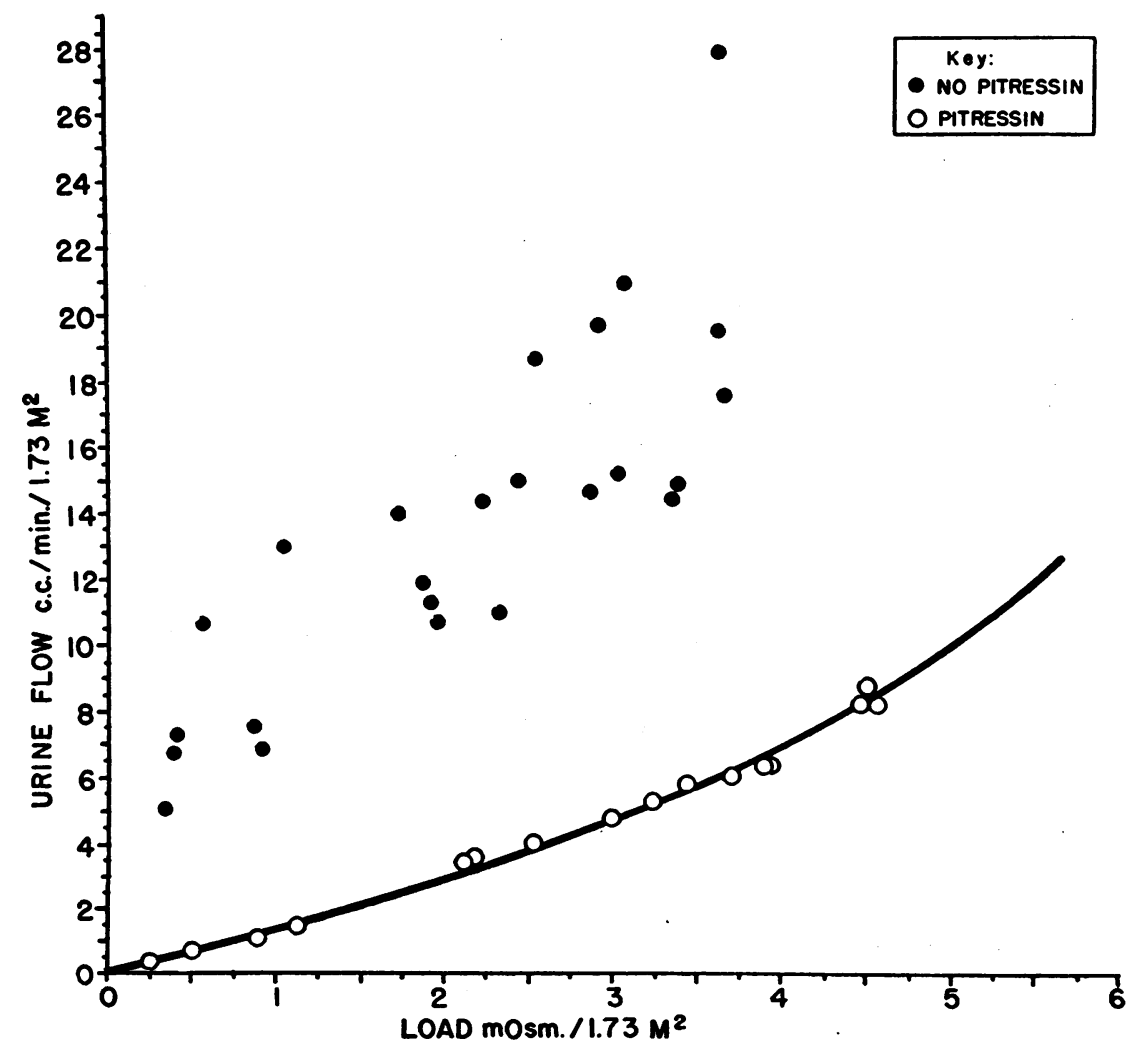

Fig. 1. UrINe Flow versus Osmotic LoAd

Open and solid circles refer to the patients with diabetes insipidus, with and without pitressin therapy, respectively. The line represents the average flow-load curve of nine normal subjects. 

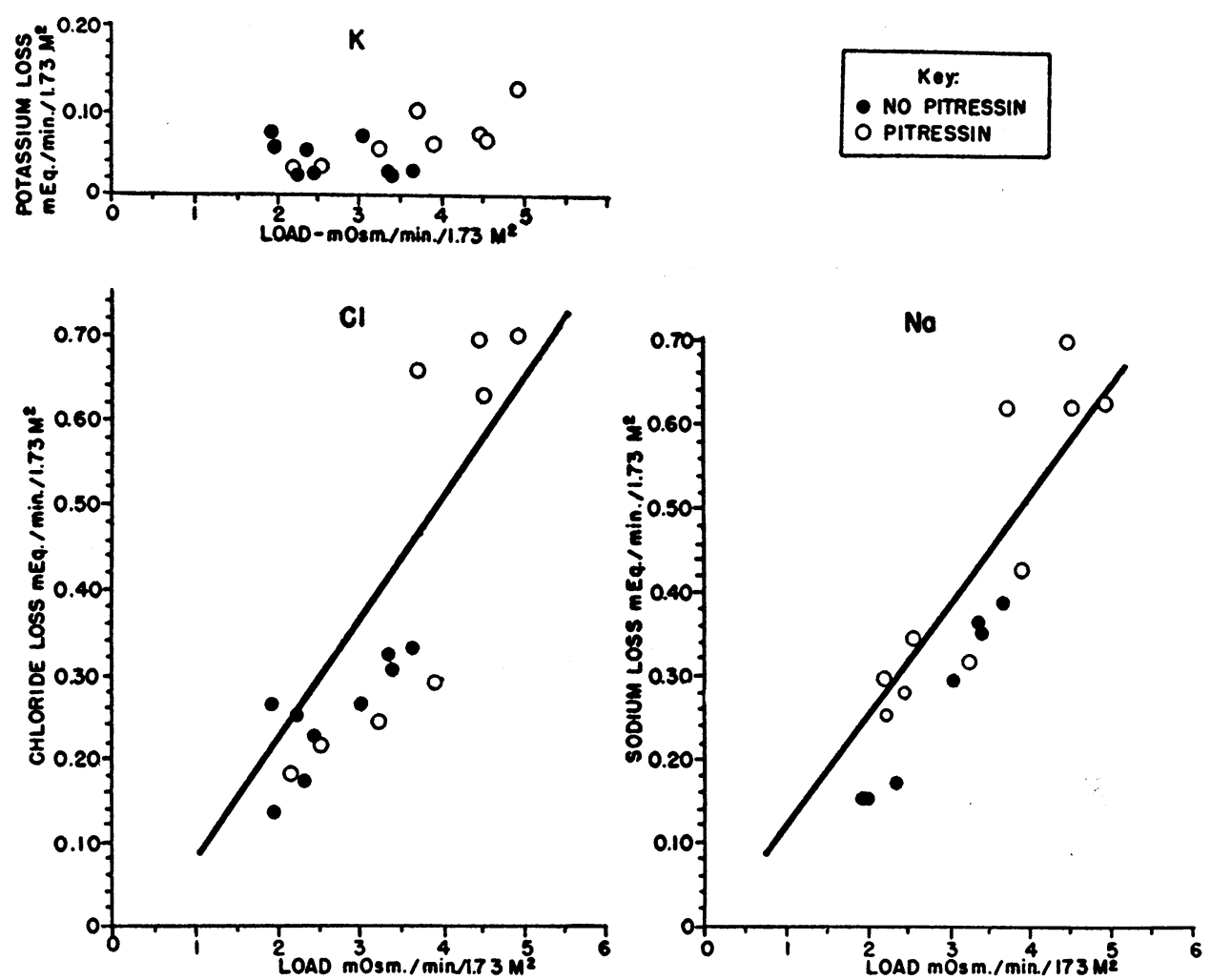

Fig. 2. Potassium, Chloride and Sodium Losses versus Osmotic Load during Mannitol LOADING

The symbols have the same meaning as in Figure 1.

ride, and potassium versus total solute load. The lines represent linear regressions calculated from nine normal hydropenic subjects under conditions of osmotic loading with mannitol. It can be seen that the data group themselves about the lines in a fairly satisfactory manner. The pattern of salt loss was the same in both pitressin-treated and untreated patients, despite the wide disparity in urine flows. Solute loading had little effect on potassium excretion in the subjects of the present study as observed previously in normal subjects (10). Mannitol excretion, not plotted, accounted for the same percentage of urinary solutes (50$60 \%$ ) as it did in normal subjects (6).

The linear relation of sodium, chloride, and mannitol to the total solute load indicates that the per cent composition of the urine in patients with diabetes insipidus during solute loading is similar to that of normal subjects. It also suggests that the final solute load destined for excretion is assembled in a portion of the tubule proximal to the site of concentration or dilution of the urine.

\section{DISCUSSION}

The observed two- to four-fold increase of urinary osmolarity in patients with diabetes insipidus after osmotic loading appears incompatible with a hypothesis which requires the delivery of a hypotonic fluid from the proximal tubule. The converse hypothesis, namely, the flow of an isotonic proximal fluid, may be tested, given the additional assumption that there exists a basal, dilute urine flow, that observed in the preliminary periods, which changes little throughout the experiment. After loading, the increment of urinary volume and load above the control level should consist of isotonic proximal fluid. This may be calculated as the increment of urinary load divided by the plasma osmolarity. Table II contains the calculations of the urine flow based on these assumptions, compared with the observed values. The data represent 23 periods of urine collection, of which 18 were obtained during loading. It can be seen that the calculated and observed rates of flow were in 
MECHANISM OF POLYURIA OF DIABETES INSIPIDUS IN MAN

TABLE II

Urine flow calculated on the assumption of constant basal flow and addition of isotonic proximal fluid

\begin{tabular}{|c|c|c|c|c|c|c|c|}
\hline \multirow{2}{*}{ Patient } & \multirow{2}{*}{ Period } & \multirow{2}{*}{$\begin{array}{l}\text { (a) } \\
\text { Load }\end{array}$} & \multirow{2}{*}{$\begin{array}{c}\text { (b) } \\
\begin{array}{c}\text { Assumed load } \\
\text { added* }\end{array}\end{array}$} & \multirow{2}{*}{ 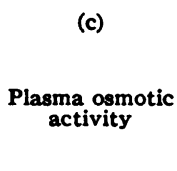 } & \multicolumn{2}{|c|}{$\begin{array}{l}\text { (d) } \\
\text { Calculated values }\end{array}$} & \multirow{2}{*}{$\begin{array}{c}\text { (f) } \\
\begin{array}{c}\text { Observed flow } \\
\text { urine }\end{array}\end{array}$} \\
\hline & & & & & $\begin{array}{l}\text { Increment } \\
\text { prox. fluid } \\
(b+c)\end{array}$ & Urinet flow & \\
\hline D. E. & $\begin{array}{c}\text { P-1 } \\
\text { P-2 } \\
\text { X-I } \\
1 \\
2 \\
\text { X-II } \\
3 \\
4\end{array}$ & $\begin{array}{c}\text { mOsm./min. } \\
0.92 \\
0.86 \\
1.88 \\
1.93 \\
1.97 \\
2.87 \\
3.04 \\
2.34\end{array}$ & $\begin{array}{c}\text { mOsm./min. } \\
\\
0.99 \\
1.04 \\
1.08 \\
1.98 \\
2.15 \\
1.45\end{array}$ & $\begin{array}{c}\text { mOsm./L. } \\
300 \\
\\
316 \\
317 \\
\\
329 \\
332\end{array}$ & $\begin{array}{l}3.14 \\
3.29 \\
3.42 \\
6.15 \\
6.67 \\
4.37\end{array}$ & $\begin{array}{c}c c . / \min . \\
\\
10.4 \\
10.5 \\
10.7 \\
13.4 \\
13.9 \\
11.6\end{array}$ & $\begin{array}{c}c c . / \min . \\
6.9 \\
7.6 \\
11.8 \\
11.3 \\
10.7 \\
14.7 \\
15.2 \\
11.0\end{array}$ \\
\hline I. W. & $\begin{array}{c}\text { P-2 } \\
\text { P-3 } \\
\text { X-I } \\
1 \\
2 \\
\text { X-II } \\
3 \\
4 \\
5\end{array}$ & $\begin{array}{l}0.39 \\
0.41 \\
1.74 \\
2.45 \\
2.23 \\
3.63 \\
3.66 \\
3.40 \\
3.36\end{array}$ & $\begin{array}{l}1.34 \\
2.05 \\
1.83 \\
3.23 \\
3.26 \\
3.00 \\
2.96\end{array}$ & $\begin{array}{l}285 \\
\\
291 \\
295 \\
\\
300 \\
304\end{array}$ & $\begin{array}{c}4.57 \\
6.99 \\
6.24 \\
10.7 \\
10.8 \\
9.93 \\
9.80\end{array}$ & $\begin{array}{l}11.6 \\
14.0 \\
13.3 \\
17.7 \\
17.8 \\
17.0 \\
16.8\end{array}$ & $\begin{array}{r}6.8 \\
7.3 \\
14.0 \\
15.5 \\
14.4 \\
19.6 \\
17.6 \\
14.9 \\
14.5\end{array}$ \\
\hline D. S. & $\begin{array}{c}\mathrm{P}-1 \\
\mathrm{X}-\mathrm{I} \\
1 \\
2 \\
\mathrm{X}-\mathrm{II} \\
3\end{array}$ & $\begin{array}{l}0.60 \\
1.04 \\
3.63 \\
2.54 \\
2.92 \\
3.07\end{array}$ & $\begin{array}{l}0.44 \\
3.60 \\
1.94 \\
2.32 \\
2.47\end{array}$ & $\begin{array}{l}282 \\
292\end{array}$ & $\begin{array}{c}1.56 \\
12.8 \\
6.88 \\
7.95 \\
8.46\end{array}$ & $\begin{array}{l}12.3 \\
23.5 \\
17.6 \\
18.6 \\
19.2\end{array}$ & $\begin{array}{l}10.7 \\
13.1 \\
27.4 \\
18.8 \\
19.9 \\
21.0\end{array}$ \\
\hline
\end{tabular}

Columns (a) and (b) present the values for the observed urinary load and its increment during loading; and column (c), the values for the osmotic activity of the plasma. The calculated increments of proximal fluid, i.e., the increment of load divided by plasma osmolarity, are presented under column (d); calculated values for the urine flow, obtained by adding the calculated increment of isotonic fluid to the basal urine flow, under column (e); and the values for the observed urine flow, under column (f).

* The assumed load added is the difference between post-loading and average pre-loading solute loads.

$\dagger$ Sum of increment of proximal fluid (d) and basal flow, taken as the average of pre-loading flows.

reasonably close agreement, the maximum deviation being $17 \%$. The close agreement between theoretical and observed urine flows supports the validity of both initial assumptions, i.e., an unchanging basal flow and addition of isotonic fluid from the proximal tubule during loading. Since the method of calculation is independent of the nature of the basal urinary flow and load, the predictions hold for a hypothesis of solute reabsorption, if a constant rate of reabsorption ${ }^{4}$ in the distal tubule both before and after loading is assumed, as well as for a hypothesis of distal secretion of water.

Direct proof for either hypothesis is not yet available. Much indirect evidence, martialled from phylogenetic, physiologic, and physico-chemical

\& The assumption of a variable rate of distal solute reabsorption would fail to explain the added flow or load observed during loading. considerations, favors a process of a distal secretion rather than one of reabsorption.

That tubular secretion occurs in the aglomerular kidney of certain marine teleosts has been shown by Marshall (11), who found, in the absence of any filtration process, production of a urine isotonic with or hypotonic to the plasma. Bieter (12) added further evidence by showing that the secretion pressure in the ureter was greater than the blood pressure in the dorsal aorta. There is no a priori phylogenetic reason to deny the existence of a secretory function for water in higher animals with glomerular kidneys.

Data from studies on water diuresis in man or dog (13-16) may be interpreted in terms of tubular secretory activity. The ingestion of water is followed by a characteristic response in urine flow. After a brief lag period the urine flow increases to a maximum and declines sharply to the initial 


\section{URINE DILUTION IN Distal tubule}
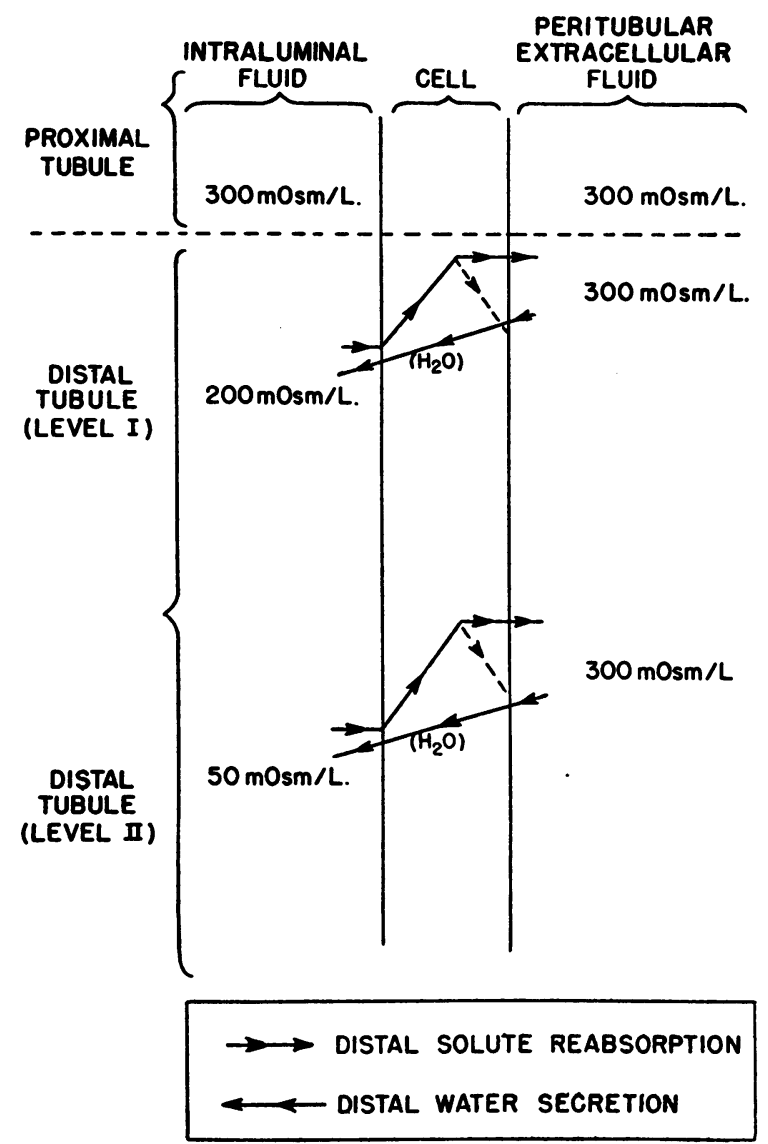

Fig. 3. Schematic Comparison of Secretory and Reabsorptive Processes of Urine Dilution in the Distal Tubule

It is assumed that the proximal and peri-tubular extracellular fluids are both isotonic with plasma, but hypertonic to the distal fluid. The assumed osmolarities are designated in the diagram. The tonicity of the final urine has been takerı as $1 / 6$ that of plasma. The lines pointing toward the left represent energy potentials for the process of secretion with the production of a fluid approaching water in composition. The lines pointing to the right represent energy potentials for an assumed process of distal solute reabsorption which requires a hypertonic reabsorbate. Two levels of the distal tubule, representing progressive stages of urine dilution, are portrayed. No definite value is assumed for the tonicity within the cell for the reabsorptive process. Alternative pathways from the cell to the extracellular fluid are drawn for the reabsorbate, solid lines representing a process of extrusion of a hypertonic fluid, and interrupted ones, a process of intracellular dilution. level. Variations in the amount or in the mode of administration of water do not affect the pattern or extent of the diuresis, provided the dose is in excess of $1 \%$ of the body weight (15b). Even while water absorption in the intestine or injection by vein still continues $(16 b, 17)$, the typical decline of diuresis takes place. Throughout the entire course of water diuresis, the filtration rate remains essentially unchanged (18-20). Hormonal and nervous factors, i.e., pituitrin, epinephrine, thyroxine, and painful or emotional stimuli, have profound effects on both the course and amount of the diuresis $(21,22)$.

This behavior resembles that of secretory glands. Their function is characterized by a specific pattern often rhythmical in nature $(23,24)$. The volume of secretion may vary independently of the blood flow (25). Nervous and hormonal factors profoundly affect their activity. Hypotonicity of secretions is well known, sweat and saliva being the outstanding examples (26).

Some of the thermodynamic implications of the production of hypotonic urine, according to the alternate assumptions of distal secretion of water or distal reabsorption of solutes, may be examined. Figure 3 is a schematic presentation of the assumed energy relations and fluid concentrations at two levels of the distal tubule. At any level in the distal tubule the concentration gradient between peri-tubular fluid and the secretion is 300 mOsm./L., while that between intra-luminal and peri-tubular fluids increases progressively. With respect to an assumed process of solute reabsorption, the less the volume of water reabsorbed, the more hypertonic must be the reabsorbate. No specific assumptions are available for the volume of fluid delivered to or reabsorbed from the distal tubule. For simplicity, a constant rate of solute reabsorption at all levels in the distal tubule has been assumed. Whatever volume of a hypertonic reabsorbate is postulated, its production will require more energy than that of a dilute secretion. ${ }^{5}$

The energy expenditure in the production of dilute urine by the distal tubule, assuming a single stage physical process, may be calculated according to the equation of von Rhorer (27).

$$
\text { 1) } \mathrm{W}=\operatorname{VRT}(\mathrm{Uln} \mathrm{U} / \mathrm{P}+\mathrm{P}-\mathrm{U})
$$

The limitations of and justifications for such a method of calculation of osmotic work have been discussed in detail elsewhere (10).

The volume of water secreted or reabsorbate removed to 
Inspection of the diagram reveals that the concentration gradient between lumen and reabsorbate at any level in the tubule is greater than that between peri-tubular fluid and a dilute secretion. Furthermore, the gradient increases progressively as the urine becomes more dilute. Whether the hypertonic reabsorbate per se is extruded into the peri-tubular space or whether it is diluted to isotonicity in the tubular cell, the process of distal

dilute a given amount of isotonic proximal fluid may be calculated as follows:

It is easily seen that

$$
\text { 2) }\left(\mathrm{O}_{\mathrm{p}}-\mathrm{O}_{\mathrm{u}}\right) \mathrm{n}
$$

is the number of solutes removed in the process of formation of dilute urine from an isotonic fluid, be it peritubular, extracellular or proximal tubular fluid, where $\mathrm{O}_{\mathrm{p}}=$ plasma osmolarity, $\mathrm{O}_{\mathrm{u}}$ urine osmolarity, and $\mathrm{n}$ the observed rate of urine flow. Then,

$$
\text { 3) } \frac{\left(\mathrm{O}_{p}-\mathrm{O}_{u}\right) n}{\mathrm{O}_{\mathrm{p}}}=\mathrm{V}_{\mathrm{s}}
$$

the volume of a secretion of water added to a given amount of isotonic proximal fluid, and

$$
\text { 4) } \frac{\left(O_{p}-O_{u}\right) n}{O_{r}}=V_{r}
$$

the volume of a reabsorbate of osmolarity $\mathrm{O}_{r}$, removed from a given amount of isotonic proximal fluid.

It follows that,

$$
\text { 5) } \mathrm{V}_{\mathrm{r}}=\left(\frac{\mathrm{O}_{\mathrm{p}}}{\mathrm{O}_{\mathrm{r}}}\right) \mathrm{V}_{\mathrm{s}}
$$

In the case of distal secretion, the concentration gradient is from peri-tubular to secretion fluid. Substituting in equation 1 ), $U$ is the concentration of the secretion, and $P$ that of the peri-tubular fluid. In the case of solute reabsorption, the gradient is from distal fluid to reabsorbate, so that $U$ would represent the assumed osmolarity of reabsorbate and $\mathrm{P}$, that of the distal fluid. As a first approximation, the osmolarity of the secretion may be taken as zero. For the reabsorbate, a series of values in multiples of plasma osmolarity are assumed. The osmolarity of the peri-tubular fluid is taken to be 300 , and the final urine, $60 \mathrm{mOsm}$./L. Substituting these values in equation 1) gives a series of relative work units which permit a comparison of energy expenditure in terms of a given volume of isotonic fluid cleared of solutes as is shown in the following table:

\begin{tabular}{|c|c|c|c|}
\hline Vol. of secretion & $\begin{array}{c}\text { Osmol. peri-tub. } \\
\text { fluid }\end{array}$ & $\begin{array}{l}\text { Osmol. of } \\
\text { secretion }\end{array}$ & Work units \\
\hline $\begin{array}{c}c c . / m i n . \\
\mathrm{V}_{.}\end{array}$ & $\begin{array}{c}\text { m Osm./L } \\
300\end{array}$ & $\begin{array}{c}m \text { Osm./L } \\
0\end{array}$ & $\begin{array}{c}W / R T \\
300 \mathrm{~V}\end{array}$ \\
\hline Vol. reabsorbate & $\begin{array}{l}\text { Osmol. distal } \\
\text { fluid }\end{array}$ & $\begin{array}{l}\text { Osmol. } \\
\text { reabsorbate }\end{array}$ & \\
\hline $\begin{array}{l}V_{s} / 2 \\
V_{s} / 3 \\
V_{s} / 4 \\
V_{s} / 10\end{array}$ & $\begin{array}{l}60 \\
60 \\
60 \\
60\end{array}$ & $\begin{array}{r}600 \\
900 \\
1,200 \\
3,000\end{array}$ & $\begin{array}{l}420 \mathrm{~V} \\
536 \mathrm{~V} \\
615 \mathrm{~V} \\
876 \mathrm{~V}^{\circ}\end{array}$ \\
\hline
\end{tabular}

TABLE III

Energy expenditure for secretory and reabsorptive process in the distal tubule solute reabsorption would seem uneconomical compared to that of distal secretion.

According to the postulate that there is a distal secretion, water is transported from an isotonic peri-tubular fluid to the tubular lumen. Such a process may be experimentally produced and is known as "negative anomalous osmosis." The factors responsible for negative osmosis depend chiefly on the characteristics of the membrane (28). A similar process of negative osmosis might result in movement of water from hypertonic distal to isotonic peri-tubular fluids, accounting for the concentration of urine in normal hydropenic subjects or in patients with diabetes insipidus when they receive pitressin. No fundamental change in membrane permeability would have to be assumed to account for either concentration or dilution of the urine by the kidney.

The large volume of glomerular filtrate renders difficult any attempt to establish the existence of a tubular secretory function. Perhaps the only acceptable direct evidence would consist of demonstration of a rate of urine flow in excess of that of filtration, under conditions of extreme reduction of filtration rate.

\section{SUMMARY}

Osmotic diuresis was produced by mannitol loading in three patients with diabetes insipidus.

During hydropenia, a flow of copious and dilute urine persisted. After loading, osmolarity of the urine rose but remained below that of plasma while the urine flow increased more than two-fold. For a given solute load the rate of excretion of urine was two to three times that of normal subjects. The urine flow was independent of changes of filtration rate or blood flow. After administration of pitressin, the relation of urine flow and solute excretion became essentially normal.

The per cent composition of urinary solutes in patients with diabetes insipidus during mannitol loading was similar to that of normal subjects suggesting that the final solute load destined for excretion is assembled in a portion of the tubule proximal to the site of concentration or dilution of the urine.

The data on urinary flow and solute load indicate that there exists a basal, dilute urine flow in diabetes insipidus, and that the increased flow ob- 
served during loading is due to the delivery of additional isotonic fluid from the proximal tubule.

It is postulated, on indirect evidence, that the distal tubule may be a special organ of water transport and that the production of hypotonic urine is due to water secretion, that of a hypertonic urine to water reabsorption, in the distal tubule.

\section{REFERENCES}

1a. Fisher, C., Ingram, W. R., and Ranson, S. W., Diabetes Insipidus and the Neuro-hormonal Control of Water Balance: A Contribution to the Structure and Furction of the Hypothalamico-Hypophyseal System. Edwards Bros., Ann Arbor, Mich., 1938.

b. Harris, G. W., Neural control of the pituitary gland. Physiol. Rev., 1948, 28, 139.

2. Shannon, J. A., The control of renal excretion of water. I. The effect of variations in the state of hydration on water excretion in dogs with diabetes insipidus. J. Exper. Med., 1942, 76, 371.

3. Walker, A. M., Bott, P. A., Oliver, J., and MacDowell, M. C., The collection and analysis of fluid from single nephrons of the mammalian kidney. Am. J. Physiol., 1941, 134, 580.

4a. Smith, H. W., The Physiology of the Kidney. Oxford University Press, New York, 1937.

b. Smith, H. W., The excretion of water (Morris Herzstein lecture). Bull. New York Acad. Med., 1947, 23, 177.

c. Wesson, L. G., Jr., Anslow, W. P., Jr., and Smith, H. W., The excretion of strong electrolytes. Bull. New York Acad. Med., 1948, 24, 586.

5a. Richards, A. N., and Plant, O. H., Urine formation in the perfused kidney. The influence of alterations on renal blood pressure on the amount and composition of the urine. Am. J. Physiol., 1922, 59, 144.

b. Verney, E. B., and Starling, E. H., On secretion by the isolated kidney. J. Physiol., 1922, 56, 353.

c. Dreyer, N. B., and Verney, E. B., The relative importance of the factors concerned in the formation of the urine. J. Physiol., 1923, 57, 451.

6. Rapoport, S., Brodsky, W. A., West, C. D., and Mackler, B., Urinary flow and excretion of solutes during osmotic diuresis in hydropenic man. Am. J. Physiol., 1949, 156, 433.

7. Handley, C. A., and Keller, A. D., Changes in renal functions associated with diabetes insipidus precipitated by anterior hypothalamic lesions. Am. J. Physiol., 1950, 160, 321.

8. West, C. D., and Rapoport, S., The glomerular filtration rate and renal blood flow during mannitol loading in hydropenic dogs. Unpublished.

9. Beaser, S. B., Renal excretory function and diet in diabetes insipidus. Am. J. M. Sc., 1947, 213, 441.

10. Rapoport, S., West., C. D., and Brodsky, W. A., Excretion of solutes and osmotic work during osmotic diuresis of hydropenic man. The ideal and the proximal tubular work; the biological maximum of work. Am. J. Physiol., 1949, 157, 363.

11. Marshall, E. K., Jr., A comparison of the function of the glomerular and aglomerular kidney. Am. J. Physiol., 1930, 94, 1.

12. Bieter, R. N., The secretion pressure of the aglomerular kidney. Am. J. Physiol., 1931, 97, 66.

13a. Priestley; J. G., The regulation of excretion of water by the kidneys. J. Physiol., 1916, 50, 304.

$b$. Priestley, J. G., The regulation of the excretion of water by the kidneys. J. Physiol., 1921, 55, 305.

14. Rioch, D. M., Water diuresis. J. Physiol., 1930, 70, 45.

15a. Heller, H., and Smirk, F. H., Studies concerning the alimentary absorption of water and tissue hydration in relation to diuresis. J. Physiol., 1932, 76, 1.

b. Heller, H., and Smirk, F. H., Tissue hydration and diuresis. II. The influence of binding an animal, of its body temperature, and of extrarenal losses of water upon diuresis. J. Physiol., 1932, 76, 23.

c. Baldes, E. J., and Smirk, F. H., The effect of water drinking, mineral starvation, and salt administration on the total osmotic pressure of the blood in man, chiefly in relation to the problems of water absorption and water diuresis. J. Physiol., 1934, 82, 62.

16a. Klisiecki, A., Pickford, M., Rothschild, P., and Verney, E. B., The absorption and excretion of water by the mammal. I. The relation between absorption of water and its excretion by the innervated and denervated kidney. Proc. Roy. Soc., London, 1933, 112B, 496.

b. Klisiecki, A., Pickford, M., Rothschild, P., and Verney, E. B., The absorption and excretion of water by the mammal. II. Factors influencing the response of the kidney. Proc. Roy. Soc., London, 1933, 112B, 521.

17. Newton, W. H., and Smirk, F. H., The effect of the intravenous administration of water upon the rate of urine formation. J. Physiol., 1933, 78, 451.

18. Walker, A. M., Schmidt, C. F., Elsom, K. A., and Johnston, C. G., Renal blood flow of unanesthetized rabbits and dogs in diuresis and antidiuresis. Am. J. Physiol., 1937, 118, 95.

19. Verney, E. B., Absorption and excretion of water; antidiuretic hormone (Sharpey Schafer memorial lecture, abridged). Lancet, 1946, 2, 739 and 781.

20. Marshall, E. K., Jr., The influence of diuresis on the elimination of urea, creatinine, and chloride. J. Pharm. \& Exper. Therap., 1920, 16, 141.

21. Verney, E. B., The antidiuretic hormone and the factors which determine its release (Croonian lecture). Proc. Roy. Soc., London, 1947, 135B, 25.

22. Pickford, M., Control of the secretion of antidiuretic hormone from the pars nervosa of the pituitary gland. Physiol. Rev., 1945, 25, 573. 
23. Albert, R. E., and Palmes, E. D., Pulsatile evaporative rates from small skin areas as measured by an infrared gas analyzer. Federation Proc., 1949, 8, 1.

24. Franke, F. E., Randall, W. C., Smith, D. E., and Hertzman, A. B., Vasomotor and sudomotor patterns in the skin of the finger and forearm. Federation Proc., 1947, 6, 105.

25. Cowgill, G. R., The salivary glands and their digestive action, in Howell, W. H., Howell's Text- book of Physiology, edited by Fulton, J. F. W. B. Saunders, Philadelphia, 1946, p. 1032.

26. Shohl, A. T., Mineral Metabolism (American Chemical Soc. Monograph Series). Reinhold Publishing Corp., New York, 1939.

27. von Rhorer, L., Ueber die osmotische Arbeit der Nieren. Arch. f. d. ges. Physiol., 1905, 109, 375.

28. Höber, R., Physical Chemistry of Cells and Tissues. The Blakiston Co., Philadelphia, 1945. 